\title{
Use of Google Apps Education to Improve Teachers Competence through Lecturer Community Service
}

\author{
Vivien Cicilia \\ SDN 1 Biromaru \\ Sigi, Indonesia \\ vivienpian98@gmail.com \\ Deitasmalina Musa
SDN 1 Tatura
Palu, Indonesia \\ Daud K Walanda \\ Universitas Tadulako \\ Palu, Indonesia \\ walanda@gmail.com
}

\author{
Lilies N Tangge \\ Universitas Tadulako \\ Palu, Indonesia \\ liliestangge@yahoo.com
}

\author{
M Jamhari \\ Universitas Tadulako \\ Palu, Indonesia \\ jamhari_mus@yahoo.co.id
}

\begin{abstract}
This study aims to determine the increase IT competence of teachers using Google Apps applications through community service activities lecturers. The samples were 32 teachers at SDN 1 Tatura. The method used is descriptive (describing) the implementation is done through a survey with data collection techniques using observation sheets about the competence of teachers using google apps before and after the community service activities of lecturers. The results showed that the implementation of the community service activities of lecturers contribute to the ability/skills of teachers at SDN 1 Tatura in using google form and constraints faced by teachers in participating in the development of IT is the lack of understanding and response of teachers to the development of IT as a means of supporting learning (google form).
\end{abstract}

Keywords-Google Apps; Teachers Competence; Lecturer Community Service

\section{INTRODUCTION}

The importance of competence in the field of IT is one of the demands of the curriculum, so teachers need to have sufficient skill or competency of IT. Various attempts were made by the school in order to equip teachers to use IT knowledge and skills of involving teachers in training activities related to the use of IT.

With regard to IT governance and the implementation of its use as a tool to help facilitate the work of the SDN 1 Tatura give a chance to the resource persons who are competent in the field of education to carry out service activities in SDN 1 Tatura, the author as one of the teachers who teach at SDN 1 Tatura, during this notice is only a few teachers who can make use of it including the android as one family in learning.

Based on the results of discussions with colleagues' (teachers at SDN 1 Tatura), one of the reasons not to make improvements ability to use IT is the age factor. The results of these discussions further communicated by the principal, so that the program work plans allocated time bringing activities of resource persons who are considered competent in their fields and can provide experience to teachers on the use of IT (including laptops and android). This opportunity was welcomed by university lecturers Tadulako Palu who have obligation to perform community service that is: Prof. Daud K Walanda, Ph. D., dan Prof. Merry Napitupulu, Ph. D., in SDN 1 Tatura Palu.

Google doc is a service of word processing, spreadsheet, presentation, form, and free web-based data storage from Google. The service was first launched on October 10th, 2006 as a merger of two services that write and spreadsheets. Presentation service was launched on September 17, 2007, while the service data storage for any file (up to a maximum of 1 GB per file) launched on January 13, 2010.

Google provides educational services known nonprofit google apps for education with free data storage and its applications are classroom, Gmail, drive, calendar, docs, sheets, slides, and sites. Google apps for education is a set of free communication tools and collaboration including email, calendar, and documents. More than 30 million students, teachers, and administrators in schools around the world use google apps for education [1].

Google drive is a change from google docs. Google drives like Dropbox is synchronizing data from a pc, which can be used to create and share data or documents on google drive, and can access data from anywhere, whether at home or from the office to connect to the internet of course. Another advantage google drive that is integrated with other Google services, including Gmail, plus, google search and more. Google drive is a storage service owned by Google, was launched since 24 April 2012. Users google drive to get service at $5 \mathrm{~GB}$ of free storage. Google drive basis, namely: (1) to create documents, spreadsheets, and images; (2) doc format in the same way that is done in the word; (3) The digital "share" documents the student (or students share their work with teachers); (4) had several students work on the same document 
at the same time; (5) have a google account all students on a spreadsheet, that share a spreadsheet with all the teachers and students so that they have an account everyone; and (6) make an assessment of students using Google forms, print using flubaroo [2].

Relation to the development of learning evaluation in order to achieve the learning objectives, application google drive that can be used is the google form. Google Forms is the beginning of the data collection framework is extremely versatile. Google form or a form called Google is a useful tool to help plan events, send a survey, give learners or others quiz, or collect the information easily in an efficient manner. Forms can also be linked to a spreadsheet.

Carroll School in Lincoln, empowering more than 400 students, 150 teachers and 50 staff members, be confident to dedicated lifelong learners. Margaret Kuzmicz, director of technology at the Carroll School, giving students access to technology that inspires them to learn, not shrink them. Many students with disabilities based language to struggle with reading and writing traditional strategies. School wants to provide an intuitive technology that can help students excel in the classroom. 2014, Kuzmicz partnered with several departments within the school, including both administrative and cognitive intervention and research team, to find a solution as unique needs will be most suitable Carroll school. Google apps for education, Chromebook, and google the class chosen because it provides the kind of experience that students in need. Google apps for education and new ways to engage students like Google expeditions help teachers save time, improve collaboration, and arouse curiosity while students discover and learn together on any device and from anywhere [3].

Google forms are a part of google drive. Thus, to create a new form, must first log in to Gmail or Google Apps. With spreadsheets makes it possible to show how to use this software to ask a variety of questions, including responding with answers to simple text or text response further. Users can ask multiple choice questions, a list of questions, questions of scale, and others. When sharing the form with others, users can set the respondent to appear with a memorable theme with easy access.

The benefits of using Google forms, namely: (1) free tool; (2) the data are automatically transferred into a google docs spreadsheet; (3) easy to use; (4) The variety of templates to create a customized look; and (5) can be used on websites, via e-mail and in webinars [4], so it is assumed that with free tools, data processing will automatically create the desired look through the website, e-mail, and webinars.

Sign on Google application form go to a page begins with Google, then log in to google then select the drive; (2) upon entry into the google drive, click "create" to create a new document, and then enter a title for the forms created in the column available and click ok.

The first step to make the questions asked, which was to determine the types of questions that will make. Then enter a title for the form to be made in the field provided and click ok. To do share, there are some settings that must be filled, namely: (1) links are used when we want to share our documents (2) if we want to change the licensing people that we share a document, for example, the person is allowed to edit or just see it ; (3) if we wanted to add people to us for our documents; (4) if we want to change permissions for a document people we we are allowed to edit and add people to share our documents; and (5) to ensure the forms created are successful, look at my yard drive.

Completion of work or everyday tasks become easier and unconsciously we are increasingly dependent on IT. Likewise, with the task and the workload in the office or at school, the information is delivered quickly and simplify management and operations of the organization. IT is a combination of information and communication technology based on computerization and information and communication technology called (ICT.) ICT serves as a means to collect, store, process, and disseminate information and knowledge in various forms and ways. Information and knowledge can be disseminated in the form of text, images, graphics, sound, animation, video, or a combination of these (multimedia) to various targets interactively through the Internet.

Teachers should equip themselves with the knowledge, skills or competencies required adequate and continuously and update it according to the needs of education services. The issue is whether teachers are ready to accept the changes proposed IT. What teachers need the competence to be able to take advantage of IT in teaching and learning process. The training program should be provided to equip teachers to use IT knowledge and skills. Teachers must understand the procedures for using the IT infrastructure in an effort to improve the quality and achievement of learning objectives. Despite facing many challenges, but the use of IT as an obligation of learning that can be overlooked [5].

Information and communication technology in learning can be used to improve accessibility and develop the relevance and quality of learning. (The World Development Report 1998/99, the New Direction of ICT-Use in Education) [5].

Technology invented by man through the application of cultivation of sense. Man must use reasonable mind by reason and then make it into a concrete product. Technology is always paired with the term science. Developments in science and technology have an exponential characteristic that is faster and faster, as the result of a stage is the basis and rationale for the next stage [6]

Information Technology emphasizes on execution and processing of data such as capturing, transmitting, storing, retrieving, manipulate or display data using the electronic technology. Emphasizing the use of communications technology electronics technology device that is more emphasis on the achievement of the objectives in the communication process, so that the processed data and information that meet the criteria of effective communication. Organize communication technology communication mechanism between the two sides by means of appropriate communication design, clear visualization, text messaging, voice, video communication standards, setting the feedback so that communication takes place in two directions [7]. 
Based on the above it can be concluded that IT competencies are skills related to the knowledge and skills of teachers in the use of computer-based means, laptop or google android as an effort to control the form in developing an evaluation of learning to achieve the learning objectives set.

Community service is one of the pillars of tri dharma and dharma research universities. Community service is an integral part tri dharma college in practice cannot be separated from the other two dharma and involve all academic faculty: faculty, students, staff, and alumni [8].

Sub-Directorate of Public Service is one of the implementing units within the Directorate of Community Service in charge of helping coordinate the implementation of community service and improving the quality of community services [8].

In addition to the target on the ability of teachers to use IT, other targets so that learners are accustomed to carrying out online evaluations independently and can be a person of high integrity in the achievement of learning objectives. This paper is focused to describe the ability of teachers to use google apps before and after the implementation of community activities lecturers and constraints faced by teachers using IT (google form).

\section{METHOD}

The method used is a survey of the teacher's ability to use google application form. The samples were 32 teachers including the principal, for Master's and honorary civil servants and administrative personnel/operator at SDN 1 Tatura year 2016/2017. The ability of teachers to use IT can be determined by observation of the ability before and after the implementation of community service activities by lecturers. The data analysis technique consists of data reduction, data presentation, and conclusion (Miles and Huberman) [9]

Data collection instrument was the observation sheet teachers' ability to use google form including the ability of teachers to follow each stage of which operated on entry to the stage using the google form.

\section{RESULTS AND DISCUSSION}

The results of the observation ability of teachers to use IT in particular google form, presented in Fig. 1 and Fig. 2.

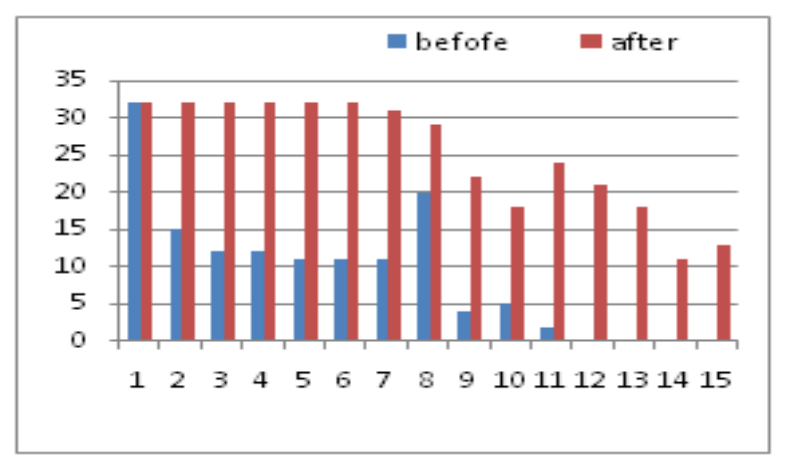

Fig. 1 Frequency

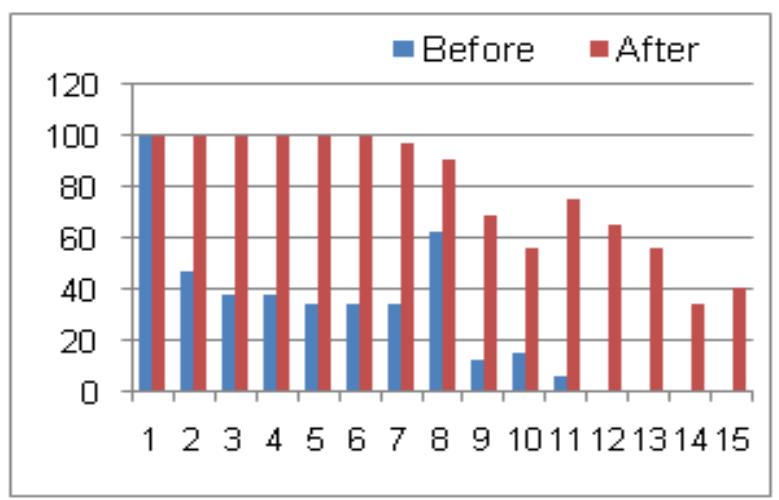

Fig. 1 Percentage

Google teacher competence on the form before community service activities by lecturers is very low. It is known from the frequency of students who can use IT related to google form. The assumption that the use of IT is not important because during this time the teacher can do it manually is one of the factors that affect the ability of teachers to take advantage of Google apps as a means of learning. Some senior teachers stated that today a lot of demands teachers to follow developments. In addition, there is also stating that age affects the ability of teachers to use IT.

Teachers can use a laptop or Android, but not prioritized to facilitate access to assessment to achieve learning objectives. Before the dedication activities of lecturers, all teachers are not yet using Google Apps education applications. Most teachers can use google just as social media facilities that are generally used as a means of communication cyberspace.

The presence of lecturers as resource persons and provide another new atmosphere for the teacher. At the time of the meeting, 32 teachers are all carrying a laptop and enthusiastically participated in the activities carried out. IT competence of teachers in using google application form can be seen from the increase in the frequency and percentage of teachers who can conduct each phase of activity.

During this time the teacher using a laptop just for typing in MS. Word and android for social media. The facility has not been used optimally in learning, especially in the development of evaluation. The reason teachers who lack a response to the use of IT by the factor of age and there is no time to practice the skills and had tried repeatedly but it is very difficult to use it.

When compared with the State of Singapore, the advancement of education in Singapore supported by adequate facilities. Every school in Singapore has free internet access, having a web school that is used to connect learners, teachers, and parents. Each class there is a liquid crystal display (LCD) for the learning process. Another factor is the factor of educators. The screening process to be very strict teachers and prospective teachers who received matched with the number of teachers needed so that all prospective teachers are bound to get a job. After auditioned, prospective teachers are given training before work, so that teachers already have a previous briefing [10]. 
Each individual has a different effect on the changes made. The process of change is influenced by personal and professional life, which both make great and the speed of change makes a difference to the final outcome of change. The speed of change has a great influence. Changes are slow results and a greater reaction than the rapid changes. The pace of change will make each individual more quickly understand what is expected of the changes and what they want to achieve, and its influence on life [11]

The assumption that the intellectual as the only yardstick of intelligence is often used as a parameter of success and the success of an individual's performance but gradually changed its paradigm because in reality not all problems can be solved by relying on intelligence alone [12].

Human resource is an asset in implementing national development in various sectors for the challenges of the global era. Human resources are determined by the results of the productivity of education management bodies consisting overcome lanes and outside the school, and specifically the result of the learning process in the classroom [13]

Although the age factor may be a reason for the weakening of the ability to think. Goleman divides five groups with the skills of emotional intelligence, namely: (1) self-consciousness (self-awareness): an awareness of the feelings that arise in the individual by recognizing a feeling that is accompanied by thinking and then take action in making decisions; (2) regulation (self-regulation): the ability to control emotions by yourself but do not just mean muffle feeling depressed or hold emotional turmoil; (3) motivation (self-motivation): the urge to improve or meet a standard of excellence, faithful to the vision and goals of the company or group, move people to accept failure and obstacles as early success; (4) social awareness (social awareness): the ability of individuals to realize himself to relate to others (social) or understand the feelings of others; and (5) social skills (social skills): is the art of dealing with the emotions of others. Emotional intelligence to teach about integrity, honesty, commitment, vision, creativity, mental endurance wisdom and self-mastery [12].

Moreover, life experiences influence skills in innovating. IT skills of teachers utilize closely related to the competency of the teacher concerned, despite the age factor is often the reason for the teacher to describe his skills were lacking in the use of IT. Competence relates to what a person can do, not just what you already know. The implication is that the competence related to what you do have to have context, competence is a result that explains what can be done by someone, measure competence should be clearly measured performance and standardization, and the measure of what a man can do can be done within a certain time, Observed means can be measured, mean survival relative competence fixed for a certain period [14].

Walter Johnson said that the professional is to ask a special task that has more than the usual degree of difficulty and require preparation time and education long enough to result in the achievement of abilities, skills, and knowledge that high levels. H.A.R Tilaar explained that a professional is someone who runs work in accordance with the demands of the profession or in other words have the ability and attitude in accordance with the demands of his profession. A professional carrying out its activities based on professionalism and not by amateurs. Professionalism contrary to amateurism [15].

The rapid changes caused by technological advances. Technology is a catalyst for change, which makes changes to be revolutionary, very quickly and intensively. This revolution is underway and the double dimension, namely linking modern brain research with the power of information and knowledge that can be accessed quickly and easily through information and communication technologies. The combined revolutioncomputers-internet world wide web (www) has formed a new generation with new values, new social force, a new culture, a new economy even the so-called digital economy. Communication and access to information become almost instantaneous, quick and easy, so activities such as trade and education can be performed simultaneously with a personal computer [16].

Two important aspects of the reform in order to implement the education reform movement, namely: (1) update the material essence of learning approaches and teaching methods, and (2) the utilization of information and communications technology to support the success of reform strategies and learning techniques. This can only be done with commitment (political will) countries to promote education [16]

Usman stated that the teacher is an office or profession that requires special expertise. Various requirements to become a teacher, including competence, mentally and physically healthy and have a teacher certificate issued by the teacher education institutions. Teacher competence is defined by the mastery of a task (teaching and educating), skills, attitudes, and appreciation are necessary for the success of the educational process that does [17].

Efforts to do in order to improve the professional competence are: (1) efforts to be made like a teacher; reading educational books, follow the latest news from the media, training, and follow KKG, conduct classroom action research (PTK), and actively participate in professional organizations and (2) efforts to be made by the principal, such as: development support teachers, supervise, organize upgrading, visits between schools, and provide the opportunity for teachers to continue education [18].

Based on the results and can be explained that in order to improve the skills of teachers in the use of IT, especially Google application form can be done by bringing in experts including lecturers in carrying out community service. Lecturers are professionals who have the competence to provide training to teachers, especially teachers at SDN 1 Tatura.

\section{CONCLUSIONS}

- Implementation of the faculty community service activities contributes to the ability and skills of teachers at SDN 1 Tatura in using google form.

- Constraints faced by teachers in participating in the development of IT is the lack of understanding and response of teachers to the development of IT as a means of supporting learning (google form). 
Based on the above conclusions, recommended suggestions are:

- Teachers need to have the competence to make use of the google form.

- The schools need to conduct continuous training included training for lecturers as resource persons.

- More intensive research to do related to this topic so as to create in-depth research and more meaningful.

- Should the lecturers provide optimal service and continue to do community service in schools, and a resource in accordance with the needs of the school/teacher.

\section{REFERENCES}

[1] T. Macdonald and T. Integration, "Google Apps for Education."

[2] G. Apps, "Google Apps for Education."

[3] M. Kuzmicz, "Carroll School Helps Students Overcome Learning Disabilities With Google For Education," 1967.

[4] L. Dokumen, "Mengenal Lebih Jauh tentang Google Form," pp. 1-5, 2007.

[5] T. Informasi, "Pemanfaatan Teknologi Informasi dan Komunikasi dalam Pembelajaran," no. 8, 2007.

[6] T. Informasi, D. A. N. Komunikasi, and A. H. Teknologi, "Teknologi Informasi dan Komunikasi (ict)," pp. 1-4.
[7] C. Riyana, "Peranan teknologi dalam pembelajaran," pp. 1-16.

[8] S. Kuliah and K. Nyata, "Direktorat Pengabdian Kepada Masyarakat," no. April, pp. 2015-2017, 2015.

[9] O. I. Agusta and P. P. Kualitatif, "Metode Kualitatif 1," no. 1998, pp. $1-$ $37,2000$.

[10] L. Belakang and D. Pendidikan, "Singapura sebagai Negara Dengan Sistem Pendidikan Terbaik di ASEAN," 2009.

[11] S. Daya, "Sumber Daya Manusia dan Manusia Bersumber Daya dalam Organisasi," vol. 7, no. 1, 2007.

[12] I. N. Hidayati, "Kecerdasan Emosional dan Kecerdasan Spiritual Pengaruhnya terhadap Kepuasan Kerja dan Kinerja Karyawan (Studi di Lembaga Penjaminan Mutu Pendidikan (LPMP) Nusa Tenggara Barat)," no. 66, pp. 629-639, 2011.

[13] A. Rofiq, "Sumber Daya Manusia Indonesia yang Berkualitas Merupakan Aset Bangsa dan Negara dalam Melaksanakan Pembangunan Nasional di Berbagai Sektor dan dalam Menghadapi Tantangan Kehidupan Masyarakat dalam Era Globalisasi,” pp. 0-41, 2009.

[14] I. Dan, T. Pembelajaran, and T. H. Utami, "Indikator dan Tujuan Pembelajaran dalam Rencana Pelaksanaan Pembelajaran," No. November 2010, pp. 0-55, 2016.

[15] P. Guru, D. I. SMK, and N. Losarang, "Faktor-Faktor yang Mempengaruhi Kompetensi Kabupaten Indramayu," 2011.

[16] U. Krisnadipayana, "Pemanfaatan ict dalam pembelajaran."

[17] F. N. M, "Kompetensi Guru dalam Peningkatan Prestasi Belajar pada SMP Negeri dalam Kota Banda Aceh," vol. 3, no. 1, pp. 45-67, 2015.

[18] K. Pedagogik, "Peningkatan Kompetensi Profesional Guru di," vol. 2, pp. 503-510, 2014. 